\title{
Case Report: Haemolytic anaemia with ceftazidime use in a patient with cystic fibrosis [version 1; peer review: 2
}

\section{approved]}

\author{
Jun Yong (D), Freddy Frost (iD, Dilip Nazareth (D), Martin Walshaw
}

Liverpool Heart and Chest Hospital NHS Trust, Liverpool, L14 3PE, UK

V1 First published: 18 Apr 2018, 7:475

https://doi.org/10.12688/f1000research.14505.1

Latest published: $18 \mathrm{Apr} 2018, \mathbf{7 : 4 7 5}$

https://doi.org/10.12688/f1000research.14505.1

\section{Abstract}

Drug-induced Immune Haemolytic Anaemia (DIIHA) is a rare but serious complication of cephalosporin use. Ceftazidime is recognized to be a rare cause of DIIHA. We report and discuss a case of DIIHA in a person with cystic fibrosis who developed severe haemolytic anaemia following use of ceftazidime in the management of an acute pseudomonal pulmonary exacerbation.

\section{Keywords}

Ceftazidime, Cephalosporins, Drug Induced Immune Haemolytic Anaemia

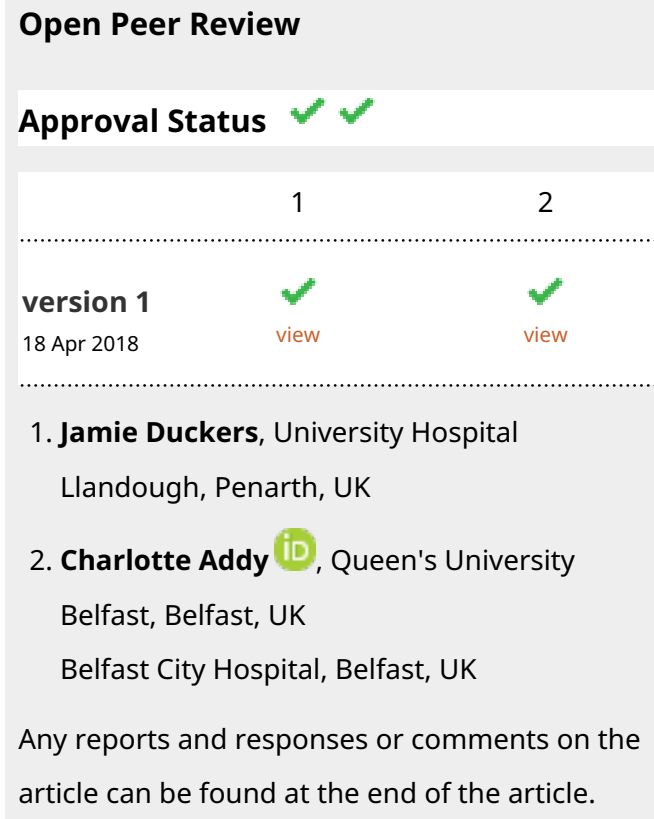

1

2

version 1

18 Apr 2018

1. Jamie Duckers, University Hospital

Llandough, Penarth, UK

2. Charlotte Addy (iD), Queen's University

Belfast, Belfast, UK

Belfast City Hospital, Belfast, UK

Any reports and responses or comments on the article can be found at the end of the article.

Corresponding authors: Jun Yong (yongjxjason@doctors.org.uk), Dilip Nazareth (Dilip.nazareth@lhch.nhs.uk)

Author roles: Yong J: Writing - Original Draft Preparation; Frost F: Writing - Review \& Editing; Nazareth D: Writing - Review \& Editing; Walshaw M: Writing - Review \& Editing

Competing interests: No competing interests were disclosed.

Grant information: The author(s) declared that no grants were involved in supporting this work.

Copyright: $\odot 2018$ Yong J et al. This is an open access article distributed under the terms of the Creative Commons Attribution License, which permits unrestricted use, distribution, and reproduction in any medium, provided the original work is properly cited.

How to cite this article: Yong J, Frost F, Nazareth D and Walshaw M. Case Report: Haemolytic anaemia with ceftazidime use in a patient with cystic fibrosis [version 1; peer review: 2 approved] F1000Research 2018, 7:475

https://doi.org/10.12688/f1000research.14505.1

First published: 18 Apr 2018, 7:475 https://doi.org/10.12688/f1000research.14505.1 


\section{Introduction}

Drug-Induced Immune Haemolytic Anaemia (DIIHA) is a serious but uncommon complication, with an estimated incidence of 1 per million of the population ${ }^{1,2}$. Since their introduction in the early 1960s, cephalosporins have been well established causes of DIIHA, most commonly with the third generation cephalosporins, cefotetan and ceftriaxone.

Ceftazidime is often a first choice cephalosporin to treat pulmonary exacerbations due to Pseudomonas aeruginosa in people with cystic fibrosis (CF), but despite its frequent use DIIHA is rare, with only 4 (non-fatal) cases being reported between 1971 to $2014^{2-4}$. For the first time, we present a case of DIIHA secondary to intravenous (IV) ceftazidime use in a person with $\mathrm{CF}$

\section{Case report}

A 23 year old female with CF (DF508/DF508) chronically infected with Pseudomonas aeruginosa presented with a 2 week history of general malaise, increasing shortness of breath, a productive cough and a decline in $\mathrm{FEV}_{1}$. She began in-patient treatment for a pulmonary exacerbation and was commenced on a 14 day course of two antipseudomonal IV antibiotics (3g of Ceftazidime and 2 Mega-Units of Colistimethate Sodium three times a day) in line with accepted CF practice. Following initial improvement, on day 4 she developed new pyrexia, hypotension, tachycardia and jaundice, and had an increasing oxygen requirement without new chest $\mathrm{X}$-ray changes.

Same day laboratory investigations confirmed severe haemolytic anaemia - haemoglobin $(\mathrm{Hb})$ had dropped from $127 \mathrm{~g} / \mathrm{L}$ on admission to $45 \mathrm{~g} / \mathrm{L}$, with new hyper-bilirubinaemia $(96 \mu \mathrm{mol} / \mathrm{L}$, normal <21) and elevated Lactate Dehydrogenase (LDH) (1806 $\mathrm{U} / \mathrm{L}$, normal $<250$ ). Haptoglobin, which binds free haemoglobin in haemolysis, was undetectable at $<0.1 \mathrm{~g} / \mathrm{L}$ (normal $0.3-2.0$ ). Subsequently, she developed a reticulocytosis $\left(145 \times 10^{\wedge} 9 / \mathrm{L}\right.$, normal range 20-110). A direct Coomb's test was strongly positive, confirming the presence of red blood cell directed antibodies. A peripheral blood smear was negative for schistocytes and a clotting screen remained normal, thus excluding thrombotic microangiopathic processes, including disseminated intravascular coagulation and thrombotic thrombocytopenic purpura. Other investigations excluded other causes of haemolysis, including paroxysmal nocturnal haemoglobinuria, mycoplasma induced haemolysis and serum electrophoresis for lymphoproliferative disorders.

A putative diagnosis of Ceftazidime-induced DIIHA was made. Initial management included stopping the IV antibiotics and transfusing 2 units of packed red cells with parenteral steroid cover. Subsequently, oral steroids (Prednisolone $50 \mathrm{mg} /$ day) were commenced and continued until induction of remission.
Once remission was achieved her steroids were to be tapered. As chronic haemolysis can induce folate deficiency, IV Folic Acid was also initiated. She improved significantly both clinically and biochemically, with her $\mathrm{Hb}$ recovering to $100 \mathrm{~g} / \mathrm{L}$ within 10 days.

\section{Discussion}

DIIHA is rare, under-recognised, and underdiagnosed, and data supporting it is poor. Often, only dramatic haemolysis leads to appropriate investigations ${ }^{2}$. DIIHA is commonly associated with the presence of drug-independent and dependent antibodies.

Drug-independent antibodies are true RBC autoantibodies, targeting RBC components and not the offending drug. It is postulated that such offending drugs affect the immune system to cause RBC autoantibody formulation and subsequent haemolytic anaemia but the exact sensitization mechanism remains unknown ${ }^{2}$.

Drug-dependent antibodies result from immune sensitization and generation of antibodies directed at epitopes on the drug and/or its metabolites, or a combination of drug and RBC membrane ${ }^{2,4}$. Specialized serological testing can confirm the diagnosis of DIIHA by demonstrating drug-dependent antibody induced haem-agglutination in vitro in the presence of the offending $\mathrm{drug}^{4}$. The identification of drug-dependent antibodies could be of clinical significance, as there is evidence suggesting that patients receiving a second course of the precipitating drug or closely related drugs may develop a more severe, even fatal haemolytic anaemia due to cross-reactive antibodies ${ }^{1,2}$. Hence, patients with cephalosporin-induced haemolytic anaemia should never receive further cephalosporins.

Clinical manifestations of DIIHA lie on a spectrum ranging from mild to severe haemolysis, with life threatening complications including acute renal failure, disseminated intravascular coagulation and shock $^{3}$. Early identification and instigation of appropriate treatment is essential. The keystone of management is the discontinuation of the precipitant drug. Glucocorticoids (1-1.5 mg/kg/day of prednisolone or equivalent in adults) are commonly employed in inducing remission via reduction in antibody production.

Our patient's DIIHA occurred following the $10^{\text {th }}$ dose of ceftazidime during her admission: this was her second course of this drug within two years. Rapid resolution of her haemolytic anaemia on cessation of ceftazidime with a high index of suspicion pre-treatment made serological testing for ceftazidime dependent antibodies unnecessary.

This case highlights the need for $\mathrm{CF}$ clinicians and microbiologists to be aware of DIIHA and its potential manifestations in order to facilitate early recognition and prompt management. 


\section{Consent}

Written informed consent for the publication of this case report was obtained from the patient.

\section{Data availability}

All data underlying the results are available as part of the article and no additional source data are required.
Competing interests

No competing interests were disclosed.

Grant information

The author(s) declared that no grants were involved in supporting this work.
1. Arndt PA, Garratty G: Cross-reactivity of cefotetan and ceftriaxone antibodies, associated with hemolytic anemia, with other: cephalosporins and penicillin. Am J Clin Pathol. 2002; 118(2): 256-62. PubMed Abstract | Publisher Full Text

2. Garratty G: Drug-induced immune hemolytic anemia. Hematology Am SoC Hematol Educ Program. 2009; 2009(1): 73-9.

PubMed Abstract | Publisher Full Text
3. Chen F, Zhan Z: Severe drug-induced immune haemolytic anaemia due to ceftazidime. Blood Transfus. 2014; 12(3): 435-7.

PubMed Abstract | Publisher Full Text | Free Full Text

4. Chambers LA, Donovan LM, Kruskall MS: Ceftazidime-induced hemolysis in a patient with drug-dependent antibodies reactive by immune complex and drug adsorption mechanisms. Am J Clin Pathol. 1991; 95(3): 393-6.

PubMed Abstract | Publisher Full Text 


\section{Open Peer Review}

\section{Current Peer Review Status:}

\section{Version 1}

Reviewer Report 26 April 2018

https://doi.org/10.5256/f1000research.15790.r33283

(C) 2018 Addy C. This is an open access peer review report distributed under the terms of the Creative Commons Attribution License, which permits unrestricted use, distribution, and reproduction in any medium, provided the original work is properly cited.

\section{Charlotte Addy}

1 Centre for Experimental Medicine, Queen's University Belfast, Belfast, UK

2 Northern Ireland Regional Adult CF Centre, Belfast City Hospital, Belfast, UK

This is a succinct and well written case report highlighting a rare but important complication of a first line anti-pseudomonal intra-venous antibiotic used commonly in Cystic Fibrosis care. It is possible this complication is under reported and without the appropriate investigations highlighted in this case may also be under-diagnosed.

The potential additions to this case are minor. In the introduction it would be useful to clarify the details of the previous four reported cases; as it is slightly unclear whether all four cases were in individuals with CF or across other diseases without tracking down each reference. Within the discussion it would also add to the clinical relevance of the case to highlight whether drug dependent antibodies show any evidence of cross-reactivity with other similar antibiotics as is seen with hypersensitivity reactions. If there is no evidence in this regard it would be useful to state this.

Otherwise I am in agreement with the previous reviewer that clinical teams are alerted to this potentially significant adverse reaction.

Is the background of the case's history and progression described in sufficient detail? Yes

Are enough details provided of any physical examination and diagnostic tests, treatment given and outcomes?

Yes

Is sufficient discussion included of the importance of the findings and their relevance to future understanding of disease processes, diagnosis or treatment? 
Is the case presented with sufficient detail to be useful for other practitioners?

Partly

Competing Interests: No competing interests were disclosed.

Reviewer Expertise: Cystic Fibrosis; Bronchiectasis

I confirm that I have read this submission and believe that I have an appropriate level of expertise to confirm that it is of an acceptable scientific standard.

Reviewer Report 24 April 2018

https://doi.org/10.5256/f1000research.15790.r33284

(C) 2018 Duckers J. This is an open access peer review report distributed under the terms of the Creative Commons Attribution License, which permits unrestricted use, distribution, and reproduction in any medium, provided the original work is properly cited.

Jamie Duckers

University Hospital Llandough, Penarth, UK

This case report details a patient with cystic fibrosis, chronically colonised with pseudomonas aeruginosa, receiving intravenous ceftazidime as part of their treatment for an acute exacerbation who develops drug induced immune haemolytic anaemia.

Ceftazidime is often used as part of the first line intravenous antibiotic regime in patients with cystic fibrosis and those with bronchiectasis who culture pseudomonas aeruginosa. This report highlights a potentially life threatening effect of this commonly used drug for which there are no firm data on frequency but haemolytic anaemia is listed on the summary of product characteristics. I would postulate that events of drug induced immune haemolytic anaemia are under reported. It is important that clinical teams remain alert to the potential undesirable effect of this well used drug, particularly as many patients may be administering ceftazidime themselves as part of home intravenous therapy regimes to treat their acute exacerbations.

Is the background of the case's history and progression described in sufficient detail? Yes

Are enough details provided of any physical examination and diagnostic tests, treatment given and outcomes?

Yes

Is sufficient discussion included of the importance of the findings and their relevance to future understanding of disease processes, diagnosis or treatment?

Yes 
Is the case presented with sufficient detail to be useful for other practitioners?

Yes

Competing Interests: No competing interests were disclosed.

Reviewer Expertise: Cystic Fibrosis, bronchiectasis

I confirm that I have read this submission and believe that I have an appropriate level of expertise to confirm that it is of an acceptable scientific standard.

The benefits of publishing with F1000Research:

- Your article is published within days, with no editorial bias

- You can publish traditional articles, null/negative results, case reports, data notes and more

- The peer review process is transparent and collaborative

- Your article is indexed in PubMed after passing peer review

- Dedicated customer support at every stage

For pre-submission enquiries, contact research@f1000.com 